\title{
Microvascular effects of corticotropin-releasing hormone in human skin vary in relation to estrogen concentration during the menstrual cycle
}

\author{
V L Clifton, R Crompton, M A Read, P G Gibson'1, R Smith \\ and I M R Wright ${ }^{2}$
}

\begin{abstract}
Mothers and Babies Research Center, Hunter Medical Research Institute, Newcastle, New South Wales, Australia
${ }^{1}$ Department of Respiratory and Sleep Medicine, Hunter Medical Research Institute, Newcastle, New South Wales, Australia

${ }^{2}$ Neonatal Intensive Care Unit, Hunter Medical Research Institute, Newcastle, New South Wales, Australia

(Requests for offprints should be addressed to I M R Wright, Neonatal Intensive Care Unit, John Hunter Hospital, Locked Bag \#1, Hunter Region Mail Center, Newcastle, New South Wales, 2310, Australia; Email: iwright@mail.newcastle.edu.au)
\end{abstract}

\begin{abstract}
Females have a significantly greater life expectancy than males, which in part may be due to the cardio-protective effects of the female sex hormone, estrogen, on vascular function. However, the sex-specific mechanisms contributing to these differences are complex and not fully understood. Previously we have reported that corticotropin-releasing hormone $(\mathrm{CRH})$ has potent dilator effects in the female skin circulation via mast cell degranulation. Furthermore the dilator response to $\mathrm{CRH}$ was more enhanced in females than in age-matched males, suggesting that estrogens may be involved. In this study we examined whether CRH-induced dilation and endothelial cell-dependent dilation in the skin circulation of pre-menopausal females were associated with changes in
\end{abstract}

estrogen during the menstrual cycle. CRH-induced dilation $(1 \mathrm{nM})$ was enhanced in the presence of high circulating concentrations of estrogen and a positive correlation was identified between $\mathrm{CRH}$-induced dilation and plasma estrogen concentrations. Endothelial celldependent dilation was examined using acetylcholine. Acetylcholine-induced dilation $(1 \mathrm{nM})$ was not correlated with circulating concentrations of estrogen. These data suggest the variation in $\mathrm{CRH}$-induced dilation in the skin microvasculature during the menstrual cycle may be due to estrogenic effects on mast cell function and not due to direct changes in endothelial cell function.

Journal of Endocrinology (2005) 186, 69-76

\section{Introduction}

Females have a significantly greater life expectancy than males, which in part may be due to the cardio-protective effects of the female sex hormone, estrogen, on vascular function (Sader \& Celermajer 2002). However, the sexspecific mechanisms contributing to these differences are complex and not fully understood. The human skin circulation has been used as a non-invasive model for the examination of peripheral vascular function (Kubli et al. 2000). Studies in this organ have demonstrated that there are differences in female vascular function in relation to the menstrual cycle and estrogen concentrations (Bartelink et al. 1990, Algotsson et al. 1995, Gerhardt et al. 2000). A number of studies have described reduced peripheral vasoconstriction during the follicular phase (Freedman \& Girgis 2000, Chan et al. 2001) and enhanced endothelialdependent vasodilation in the presence of increased estrogen concentrations during the menstrual cycle (Bungum et al. 1996, Arora et al. 1998) or following long-term estrogen therapy in post-menopausal women (Arora $e t$ al. 1998) and in men (New et al. 2000). Estrogen may promote vasodilation by increasing endothelial and smooth muscle nitric oxide (NO) production (Forte et al. 1998, Chambliss \& Shaul 2002) via estrogen receptor alpha (Chen et al. 1999, Wyckoff et al. 2001). However, evidence collected from our laboratory would suggest there may be an alternate mast cell pathway involved in the regulation of skin vascular tone (Crompton et al. 2003) that could also be affected by changing concentrations of estrogen during the menstrual cycle (Clifton et al. 2002).

Previously we have reported that corticotropinreleasing hormone $(\mathrm{CRH})$, a 41 amino acid peptide produced predominately in the central nervous system, has potent dilator effects in the female skin circulation when compared with age-matched males (Clifton et al. 2002). Human skin is a known target organ for $\mathrm{CRH}$ and proopiomelanocortin (POMC) peptides, and localization studies have demonstrated that $\mathrm{CRH}$, its related peptide urocortin, and POMC proteins and genes are expressed in 
the basal layer of the epidermis and also in pilosebaceous cells (Kono et al. 2001, Slominski et al. 2001). This indicates that human skin cells locally produce $\mathrm{CRH}$ and POMC peptides and supports the proposal that a stressresponse system similar to the hypothalamic-pituitaryadrenal axis may exist in the skin (Slominski et al. 2001).

We have identified that CRH-induced dilation in the skin circulation is via mast cell degranulation (Crompton et al. 2003). Mast cells are necessary for the development of allergic reactions, often exacerbated by stress and invading pathogens. Mast cells are found in large numbers in the skin (7000-20 000 mast cells $/ \mathrm{mm}^{2}$ ) (Schmolke et al. 1994) and are located in the subpapillary region, around blood vessels, lymphatic structures, epithelial appendages and nerves (Eady et al. 1979, Wiesner-Menzel et al. 1981, Charlesworth 1997), suggesting that mast cells may have multiple roles in the skin, including the control of blood flow. Previous studies indicate that mast cells are responsive to neuropeptides such as substance $\mathrm{P}$, vasoactive intestinal polypeptide and somatostatin (Lowman et al. 1988, Benyon 1989) and CRH receptors have been localized on mast cells (Slominski et al. 2001), suggesting they would be responsive to $\mathrm{CRH}$ and its related peptides. Theoharides et al. (1998) and Singh et al. (1999) have reported that both $\mathrm{CRH}$ and urocortin increased vascular permeability in rat skin via mast cell degranulation.

Mast cell degranulation involves the release of numerous vasoactive molecules, including histamine and $\mathrm{NO}$ (Maurer et al. 2003). CRH-induced vasodilation in human skin appears to be mediated by mast cell-derived histamine, as we demonstrated that promethazine hydrochloride, a histamine-1 $\left(\mathrm{H}_{1}\right)$ receptor antagonist, significantly reduced CRH-mediated effects (Crompton et al. 2003). However, the $\mathrm{H}_{1}$ receptor antagonist did not completely inhibit the $\mathrm{CRH}$-induced dilation (Crompton et al. 2003), suggesting that other vasodilator molecules may be involved. This is consistent with a study by Theoharides et al. (1998) whereby partial inhibition of the $\mathrm{CRH}$-induced vascular permeability in rat skin was observed in the presence of the $\mathrm{H}_{1}$ receptor antagonist, diphenhydramine. Our work indicates that CRHinduced dilation in human skin may also be mediated via histamine-2 $\left(\mathrm{H}_{2}\right)$ receptors, as the presence of the $\mathrm{H}_{2}$ receptor antagonist, ranitidine, partially reduced the CRH-induced dilation (Crompton et al. 2003). Previous studies support this work as it has been reported that histamine-induced dilation in the skin is mediated via both $\mathrm{H}_{1}$ and $\mathrm{H}_{2}$ receptors (Grossmann et al. 1999).

A number of studies have also indicated that $\mathrm{CRH}-$ induced dilation is mediated via the NO pathway. Clifton et al. (1995) reported that CRH was a potent dilator in the human fetal-placental circulation and was mediated via NO and cGMP. Jain et al. (1997) demonstrated that CRH caused dilation in pregnant rat mesenteric arteries via NO. NO synthase (NOS) has been localized in mast cells of the human lung (Gaston et al. 1994) and the skin vascular endothelium (Abd-El-Aleem et al. 2000) suggesting that both of these sites are potential sources of $\mathrm{NO}$ in human skin. In our study the inhibition of NOS using $\mathrm{N}_{\omega}$-nitroL-arginine methyl ester blocked CRH-induced vasodilation in the human skin circulation (Crompton et al. 2003). Conversely Theoharides et al. (1998) demonstrated that inhibition of $\mathrm{NO}$ synthesis potentiated $\mathrm{CRH}$-induced vascular permeability in rat skin. Our work indicates that vasodilator molecules such as histamine and $\mathrm{NO}$ released from mast cells may act together to play a role in the $\mathrm{CRH}$-induced vasodilation in human skin (Crompton et al. 2003). Histamine-induced dilation is also mediated by NO (Feldman et al. 1996), suggesting that endothelialderived NO may play a role in $\mathrm{CRH}$-induced dilation in human skin. These studies suggest $\mathrm{CRH}$-induced dilation in human skin may be mediated via histamine and NO derived from mast cell degranulation and/or histamineinduced NO production from the vascular endothelium.

Enhanced CRH-induced dilation in pre-menopausal females when compared with age-matched males may be due to the effects of estrogen on mast cell pathways or endothelial-smooth muscle cell pathways. Estrogen receptor $\beta$ is widely distributed in the epidermis, blood vessels, dermal fibroblasts and hair follicles of the human (Thornton et al. 2003), suggesting estrogen may have several different functions in skin, including the regulation of vascular tone during the menstrual cycle. There have been no specific reports of estrogen receptor localization in skin mast cells but this receptor has been localized in human mast cells of the bladder (Pang et al. 1995), lung (Zhao et al. 2001) and arterioles (Nicovani \& Rudolph 2002). Furthermore in rat peritoneal mast cells, $17 \beta$-estradiol activated mast cell histamine and serotonin secretion (Vliagoftis et al. 1992), suggesting mast cell degranulation can be directly regulated by this steroid. Based on this information we initiated the present study to examine the association between changes in estrogen concentration during the menstrual cycle and vascular responses to $\mathrm{CRH}$, acetylcholine and heat. This work would provide evidence of whether estrogen is associated with changes in skin vascular tone either via a mast cell pathway as demonstrated by CRH-induced dilation or an endothelialdependent pathway as demonstrated by acetylcholine- and heat-induced dilation.

\section{Materials and Methods}

\section{Experimental subjects}

Non-smoking, pre-menopausal females $(n=11,21-41$ years), with regular menstrual cycles of 28-32 days, who were not using an oral contraceptive, were recruited to the study following guidelines approved by the Hunter Area Health Human Ethics Committee and The University of Newcastle Occupational Health and Safety Committee. The examination of skin microvascular function was 
performed on the volar aspect of the forearm. Subjects with any generalized dermatitis or essential hypertension were excluded. Women were tested at days 6, 16 and 26 of the menstrual cycle in consecutive months for $\mathrm{CRH}$ and acetylcholine. These intervals were calculated from day 1 of menses for each individual woman and approximately coincide with the follicular, mid-cycle and luteal phases respectively. A plasma sample was obtained on each of these days for the measurement of estrogen and progesterone. Subject weight, height and age were assessed. Subjects refrained from coffee and food for at least $1 \mathrm{~h}$ before the investigation.

\section{Drugs}

Synthetic human CRH was obtained from Auspep (Melbourne, Australia). Acetylcholine chloride was obtained from the Sigma Chemical Company.

\section{Laser Doppler and iontophoresis}

Microvascular laser Doppler is an established method of assessing the function of blood vessels of the peripheral microvasculature (Kubli et al. 2000). Low-intensity laser light is reflected from moving blood cells in the skin circulation and thus a measurement of blood flow is obtained. We used a Periflux 5001 Laser Doppler (Perimed $\mathrm{AB}$, Järfalla, Sweden) with one temperatureregulated iontophoresis probe and one temperatureregulated control probe sited on the anterior aspect of the forearm. The PerIont micropharmacology system was used (Perimed). This system is described elsewhere ( $\mathrm{Hu}$ et al. 1998). Briefly, a transdermal current is applied to cause migration of drugs from a disposable electrode, surrounding the temperature-controlled laser Doppler transducer, into the skin. Blood flow readings are expressed as arbitrary perfusion units (PUs).

\section{Experimental protocol}

Subjects were placed in a semi-supine position and skin basal blood flow was recorded for 5 min, after which six doses of CRH $(1 \mathrm{nM})$, acetylcholine $(1 \mathrm{nM})$ or vehicle controls (distilled water) were administered to the skin circulation, on separate occasions, by iontophoresis at a current of $0.06 \mathrm{~mA}$ for $30 \mathrm{~s}$ per dose with a positive polarity. Blood flow was recorded by laser Doppler after each dose. CRH and acetylcholine were measured separately in consecutive months on days 6, 16 and 26 . Consistency of the data collected on individuals who received both $\mathrm{CRH}$ and acetylcholine treatments was ensured by comparing the blood flow response to heat between each treatment day or each month. There was no significant difference in response to heat between months (data not shown).
As described previously ( $\mathrm{Hu}$ et al. 1998), certain standard provocations were performed to allow for comparison between different studies and subjects. After the last iontophoretic stimulation and when skin perfusion had returned to a stable level, a blood pressure cuff was used to examine a short period of absent blood flow and the re-perfusion capacity of the circulation in the control probe. This allowed for a biological zero to be obtained in each experiment. Forearm blood flow was then allowed to stabilize before a standard thermal provocation was then used. A small heater around the control probe increased the temperature setting from 40 to $44^{\circ} \mathrm{C}$ in $1^{\circ}$ increments at $60 \mathrm{~s}$ intervals. The reactive hyperemia following the heat provocation was monitored by the laser Doppler. At the time of the iontopheresis procedure, a blood sample was obtained from each subject for steroid hormone measurement.

\section{Measurement of estrogen and progesterone}

Serum $17 \beta$-estradiol and progesterone levels were measured at day 6,16 and 26 of the menstrual cycle using commercial RIA kits (Immulite 2000; Diagnostic Products Corp., Los Angeles, CA, USA).

\section{Data analysis}

Dose-response curves were compared using generalized estimating equations (GEEs) using the statistical software, STATA (version 7 2001; STATA Press, College Station, TX, USA). Pearson's correlation was used for comparison of age, weight and height with responses to $\mathrm{CRH}$ and acetylcholine (Graphpad Instat, Graphpad Software 1990-1993, Version 2.04a). All values were expressed as means \pm S.E.M. unless otherwise stated. $P<0 \cdot 05$ was considered significant.

\section{Results}

The mean age of women in this study was $26 \cdot 9 \pm 2 \cdot 1$ years. The mean weight of the subjects was $63 \cdot 0 \pm 2 \cdot 8 \mathrm{~kg}$, mean height $163 \cdot 3 \pm 2 \cdot 2 \mathrm{~cm}$ and mean body mass index 23.6. The mean length of the menstrual cycle was $28.5 \pm 1 \cdot 2$ days. Some women had longer menstrual cycles than others, with their highest concentration of $17 \beta-$ estradiol occurring on day 26 rather than day 16 (Fig. 1). Consequently we used the highest estradiol value for each subject, at either day 16 or 26 , and then compared the results with $17 \beta$-estradiol levels on day 6 of the cycle. Accordingly the data were analyzed based on low and high estrogen concentrations.

The mean serum concentrations of low $17 \beta$-estradiol was $131 \cdot 8 \pm 8 \cdot 4 \mathrm{pM}$ (day 6 ) and high $17 \beta$-estradiol was 


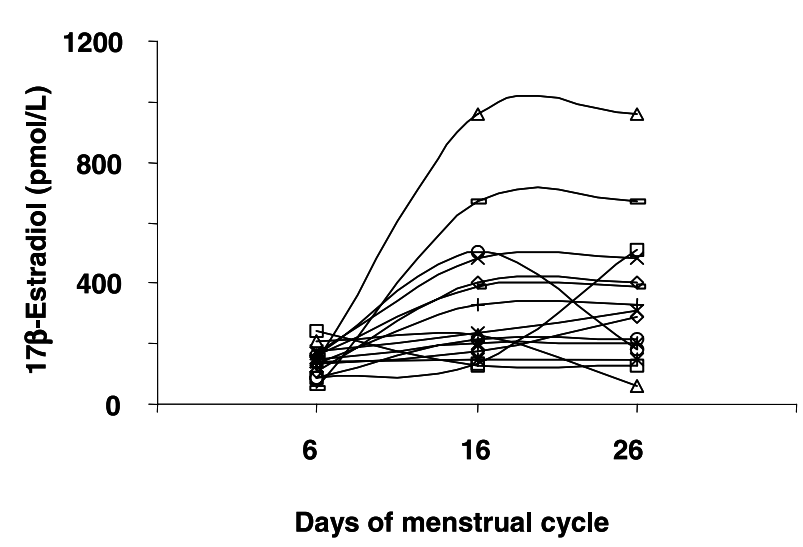

Figure 1 Comparison of individual $17 \beta$-estradiol concentrations on days 6,16 and 26 of the menstrual cycle. Pre-menopausal women $(n=11)$ had variable $17 \beta$-estradiol concentrations during their menstrual cycle, with some women having the highest concentration at day 26.

$579 \cdot 5 \pm 154 \cdot 5 \mathrm{pM}$ (day 16-26). Serum progesterone levels corresponding to low and high estrogen levels were $1 \cdot 0 \pm 0 \cdot 1$ and $21 \cdot 9 \pm 4 \cdot 8 \mathrm{nM}$ respectively.

Biological zero, basal skin microvascular flow and postocclusive re-perfusion were not significantly different in the presence of high and low serum $17 \beta$-estradiol concentrations (paired $t$-test $P>0 \cdot 05$ ). Heat-induced hyperemia was significantly enhanced in the presence of high circulating concentrations of estrogen (GEE, $P<0 \cdot 05$ ) (Fig. 2).

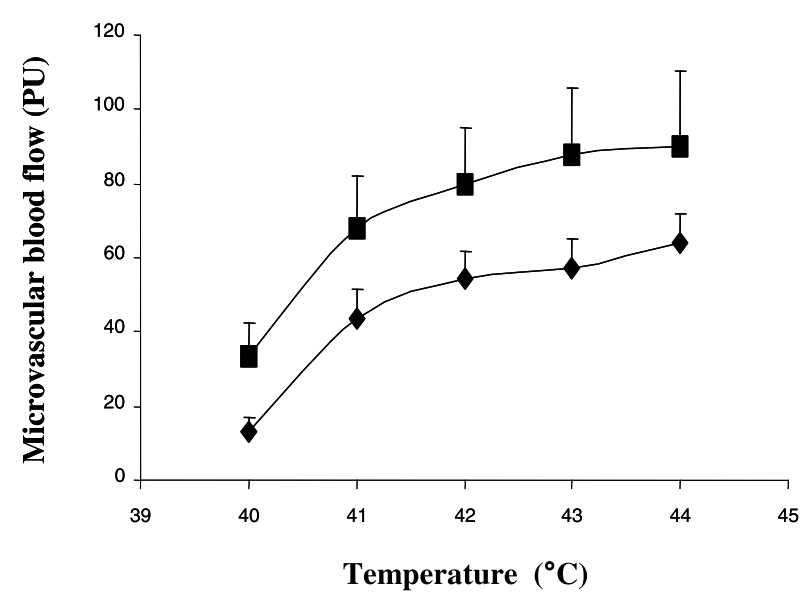

Figure 2 Comparison of heat-induced vasodilation in female skin circulation during the menstrual cycle. Heat-induced dilation was significantly increased in the presence of high circulating concentrations of $17 \beta$-estradiol ( $n=11, \mathbf{\square}$, day 16-26) when compared with low circulating concentrations of $17 \beta$-estradiol $(n=11, \bullet$, day 6$)\left(\mathrm{GEE},{ }^{*} P \leq 0 \cdot 001\right)$ during the menstrual cycle. Microvascular skin blood flow was measured in PUs as a small heater around the head of the control probe increased the temperature setting from 40 to $44^{\circ} \mathrm{C}$ in $1^{\circ}$ increments at $60 \mathrm{~s}$ intervals. The reactive hyperemia following the heat provocation was monitored by the laser Doppler. All values are expressed as means \pm S.E.M.

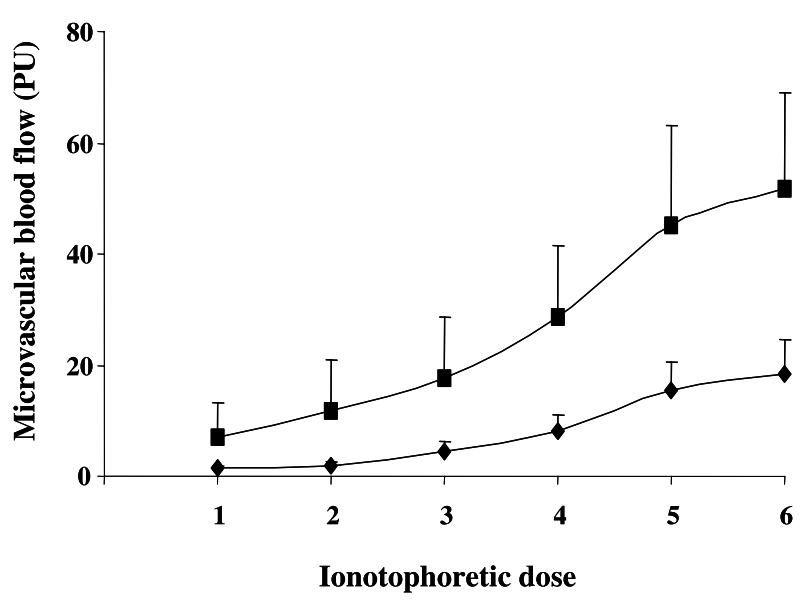

Figure 3 Comparison of $\mathrm{CRH}$-induced vasodilation in female skin circulation during the menstrual cycle. $\mathrm{CRH}$-induced dilation was significantly increased in the presence of high circulating concentrations of $17 \beta$-estradiol ( $1 \mathrm{nM}, n=11$, $\mathbf{\square}$, day 16-26) when compared with $\mathrm{CRH}$-induced dilation in the presence of low circulating concentrations of $17 \beta$-estradiol $(1 \mathrm{nM}, n=11$, day 6$)$ $\left(\mathrm{GEE},{ }^{*} P \leq 0 \cdot 001\right)$ during the menstrual cycle. Microvascular skin blood flow was measured in PUs, and CRH was administered by six $30 \mathrm{~s}$ pulses of a positive electrical current at $0.06 \mathrm{~mA}$. All values are expressed as means \pm S.E.M.

Human CRH (1 nM) caused a dose-dependent vasodilation in the skin microvascular circulation (Fig. 3). $\mathrm{CRH}$-induced dilation was significantly greater in the presence of high circulating concentrations of estrogen when compared with low concentrations of estrogen $(n=11$, GEE, $P<0 \cdot 05)$ (Fig. 3). There was no correlation between the $\mathrm{CRH}$-induced dilation and subject age, weight or height.

There was a positive correlation between estrogen concentrations and the effect of $\mathrm{CRH}$ on blood flow $\left(n=11, R^{2}=0 \cdot 53, P<0 \cdot 0001\right)$ and no correlation between progesterone concentrations and $\mathrm{CRH}\left(n=11, R^{2}=0 \cdot 01\right.$, $P=0 \cdot 523$ ).

Acetylcholine (1 $\mathrm{nM})$ caused a dose-dependent dilation in female subjects $(n=6)$ and these responses were not significantly different in the presence of low and high estrogen concentrations (Fig. 4) (GEE, $P>0 \cdot 05$ ). There was no correlation between estrogen $\left(n=6, R^{2}=0 \cdot 0006\right.$, $P=0.92)$ or progesterone $\left(n=6, R^{2}=0 \cdot 03, P=0.51\right)$ concentrations and maximal dilator response to acetylcholine throughout the menstrual cycle. There was no correlation between response to acetylcholine and subject age, weight or height.

\section{Discussion}

We have previously reported that $\mathrm{CRH}$-induced dilation in the skin microvasculature was more enhanced in 


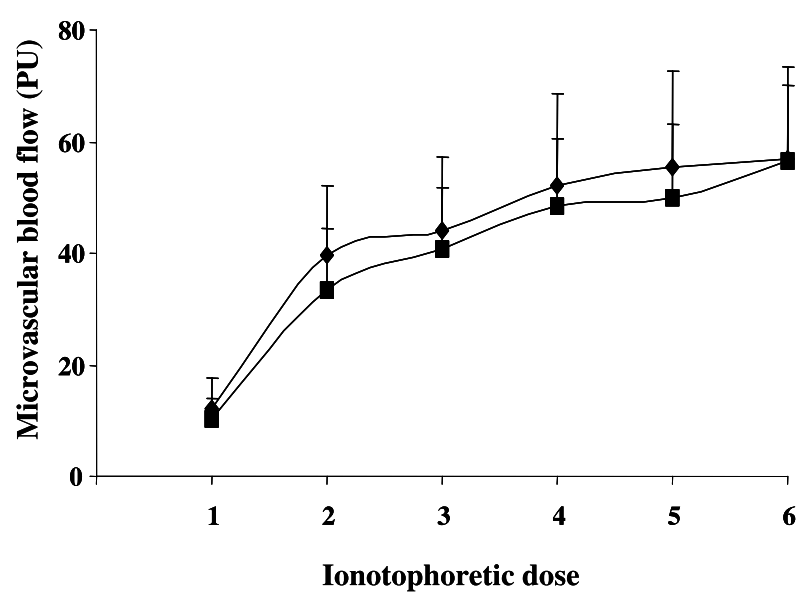

Figure 4 Comparison of acetylcholine-induced vasodilation in female skin circulation during the menstrual cycle. Acetylcholine-induced dilation was not significantly altered in the presence of high ( $1 \mathrm{nM}, n=6, \boldsymbol{\square}$, day 16-26) and low (1 nM, $n=6$, $\bullet$, day 6 ) circulating concentrations of $17 \beta$-estradiol (GEE, $P>0.05)$ during the menstrual cycle. Microvascular skin blood flow was measured in PUs, and acetylcholine was administered by six $30 \mathrm{~s}$ pulses of a positive electrical current at $0.06 \mathrm{~mA}$. All values are expressed as means \pm S.E.M.

pre-menopausal females when compared with agematched males (Clifton et al. 2002) and that CRHinduced vasodilation occurred primarily via mast cell degranulation and was partially mediated by histamine, prostaglandins and NO (Crompton et al. 2003). In our present investigation we have determined that $\mathrm{CRH}-$ induced dilation in the skin microvasculature of premenopausal females is positively correlated with circulating concentrations of endogenous estrogen. However, there was no correlation between estrogen concentrations and endothelial-induced dilation with acetylcholine. These data suggest that changes in skin microvascular function in response to $\mathrm{CRH}$ may be linked to alterations in mast cell function rather than direct changes to endothelial function during the menstrual cycle.

Variations of female cardiovascular function during the menstrual cycle are known to be associated with changes in circulating estrogen levels (Hashimoto et al. 1995, Kawano et al. 1996, Giannattasio et al. 1999, Gerhardt et al. 2000). Arora et al. (1998), using iontophoresis and laser Doppler, demonstrated that skin micovascular dilator responses to acetylcholine and sodium nitroprusside were enhanced in mid-cycle pre-menopausal females and postmenopausal females receiving estrogen replacement therapy, when compared with post-menopausal females who had not received estrogen supplements. Williams et al. (2001) examined acetylcholine- and sodium nitroprusside-induced dilation in the skin microvasculature of 15 pre-menopausal females at four time points during the menstrual cycle and reported an enhanced response to acetylcholine in the late follicular phase.
However, these changes did not appear to be correlated with the changes in circulating estrogen levels (Williams et al. 2001). In agreement with these findings, our study has similarly demonstrated that acetylcholine-induced dilation is not correlated with circulating concentrations of estrogen during the menstrual cycle. We did not find an enhanced response to acetylcholine in the follicular phase as reported by Williams et al. (2001). The discrepancy between the two studies may be due to methodological differences as we used fewer subjects, a lower concentration of acetylcholine and measured blood flow directly from the chart recording after multiple administrations of the drug, while Williams et al. (2001) administered the drug once and then quantified the change in blood flow by measuring the area under the curve. Based on these differences between the studies these findings need to be investigated further.

In the coronary circulation, acute administration of estrogen to post-menopausal women enhanced acetylcholine-induced dilation (Gilligan et al. 1994, Pinto et al. 1997). Flow-mediated dilation in the brachial artery was enhanced in pre-menopausal women due to increased endothelial NO production and was associated with changes in circulating concentrations of estrogen (Hashimoto et al. 1995, Sudhir et al. 1996). Majmudar et al. (2000) examined vascular responses to NO inhibition in the brachial artery of pre-menopausal females and concluded enhanced vasodilation was due to increased endothelial NO production when compared with postmenopausal females and males. Furthermore, long-term estrogen replacement therapy in post-menopausal women restored endothelial NO production to levels similar to those observed in pre-menopausal women (Majmudar et al. 2000). Since endothelial-dependent vasodilation using acetylcholine did not change with increased circulating estrogen levels in our study, we cautiously conclude that other factors regulated by estrogen, such as mast cell pathways, may play a role in modulating vascular tone in the skin during the menstrual cycle.

Estrogens are known to modulate mast cell function in the human. Kim et al. (2001) reported that a human clonal mast cell line, HMC-1, reduced its release of proinflammatory cytokines following incubation with estrogen in vitro. IgE-mediated histamine release from rat peritoneal mast cells and human basophils in vitro is enhanced following incubation with estrogen (Cocchiara et al. 1990). Mast cell degranulation may be increased during the menstrual cycle, as demonstrated by the correlation of urinary histamine metabolites and plasma estrogen concentrations in pre-menopausal women (Jonassen et al. 1976). Furthermore, responses to histamine in skin prick tests and in the nasal mucosa of atopic and nonatopic pre-menopausal women are greatest at mid-cycle (Kalogeromitros et al. 1995, Haeggstrom et al. 2000). From our study, the enhanced response to CRH-induced dilation in association with increased circulating estrogen 
concentrations may be caused by increased mast cell degranulation in female skin.

There are several different vasoactive substances released by mast cells that may affect vascular tone (Boesiger et al. 1998, Kim et al. 2001), with histamine being the most widely measured factor (Maurer et al. 2003). Our research indicates histamine, prostaglandins and NO may mediate CRH-induced dilation in the skin (Crompton et al. 2003). When we examined histamineinduced dilation in the skin microvasculature of premenopausal women at mid-cycle and compared the response with that in males, we found there was no significant difference between the sexes (Crompton et al. 2003) even though there was a significant difference in $\mathrm{CRH}$-induced dilation between the sexes (Clifton et al. 2002). Furthermore, when we examined endotheliumdependent dilation using acetylcholine between agematched males and females we also observed no significant difference in the response (Clifton et al. 2002). It was concluded from this work that $\mathrm{CRH}$-induced dilation in the skin microvasculature may be mediated by histamine and NO, but these factors alone did not account for the difference in response to $\mathrm{CRH}$ between males and females (Clifton et al. 2002). These data suggest that alterations in the skin CRH-mast cell pathway may be influenced by the different phases of the menstrual cycle.

$\mathrm{CRH}$ and urocortin act via the $\mathrm{CRH}$ receptor isoforms, type 1 and 2 (Aguilera et al. 2004). In human skin, the type $1 \alpha$ isoform is expressed in most cell types of the epidermis and dermis (Slominski et al. 2004). The type 2 isoform is found in hair follicles, sebaceous glands and blood vessels (Slominski et al. 2004). CRH and urocortin may act via the type $1 \mathrm{CRH}$ receptor on skin mast cells, as the type 1 receptor mediates cardiac mast cell degranulation in the rat (Pang et al. 1998). Our data suggest that the response to $\mathrm{CRH}$ in the skin microvascular circulation is mediated via a CRH receptor, as we were able to suppress $\mathrm{CRH}$-induced dilation by the administration of a $\mathrm{CRH}$ antagonist, $\alpha$-helical $\mathrm{CRH}_{(9-41)}$ (Clifton et al. 2002). Previous studies in the human placental circulation suggest that $\mathrm{CRH}$-induced dilation is mediated by a type $2 \mathrm{CRH}$ receptor (Leitch et al. 1998) and the NO pathway (Clifton et al. 1995). It is possible that CRH-induced dilation in the skin could be mediated by $\mathrm{CRH}$ receptors 1 and 2 present on mast cells and the endothelium respectively.

We have observed an increased skin vasodilator response to hyperemia with high circulating concentrations of estrogen. Other studies have shown that the skin response to heat is more enhanced in pre-menopausal females than males (Bartelink et al. 1993). High concentrations of combination oral contraceptives, ethinyl estradiol and progestin, in pre-menopausal women are associated with an enhanced vasodilator response to increased skin temperature when compared with low concentrations of these hormones (Charkoudian \&
Johnson 1999a). These data suggest that female sex steroids influence the thermal control of skin blood flow. The vasodilator response to increased skin temperature is partially mediated by NO (Kellogg et al. 1998, Shastry et al. 2000), but not via acetylcholine muscarinic receptors (Shastry et al. 2000) or prostaglandins (Charkoudian \& Johnson 1999b). Since there was no association between endothelial-induced dilation and estrogen in our study, it is possible that the changes in the vasodilator response to heat may be due to estrogen effects on the neuromuscular or endocrine cells of the skin.

This study indicates that circulating estrogen concentrations influence $\mathrm{CRH}$-induced dilation in the female skin microcirculation. Interestingly, acetylcholine-induced dilation did not vary with estrogen concentrations during the menstrual cycle. However, this finding requires further investigation and may only be relevant to the skin circulation. These data, and in combination with our previous studies (Clifton et al. 2002, Crompton et al. 2003), suggest that the variation in CRH-induced dilation during the menstrual cycle is due to alterations in mast cell function. These studies highlight that some components of the immune system have a role in the control of skin vascular function and may be a contributing mechanism to the cardio-protective effects of estrogen.

\section{Funding}

This work was supported by grants from the John Hunter Hospital Charitable Foundation, the NSW Government and the Hunter Medical Research Institute. The authors declare that there is no conflict of interest that would prejudice the impartiality of this scientific work.

\section{References}

Abd-El-Aleem SA, Ferguson MW, Appleton I, Kairsingh S, Jude EB, Jones K, McCollum CN \& Ireland GW 2000 Expression of nitric oxide synthase isoforms and arginase in normal human skin and chronic venous leg ulcers. Journal of Pathology 191 434-442.

Aguilera G, Nikodemova M, Wynn PC \& Catt KJ 2004 Corticotropin releasing hormone receptors: two decades later. Peptides $\mathbf{2 5}$ 319-329.

Algotsson A, Nordberg A \& Winblad B 1995 Influence of age and gender on skin vessel reactivity to endothelium-dependent and endothelium-independent vasodilators tested with iontophoresis and a laser Doppler perfusion imager. Journal of Gerontology. Series A, Biological Sciences and Medical Sciences 50 M121-M127.

Arora S, Veves A, Caballaro AE, Smakowski P \& LoGerfo FW 1998 Estrogen improves endothelial function. Journal of Vascular Surgery 27 1141-1146; discussion 1147.

Bartelink ML, Wollersheim H, Theeuwes A, van Duren D \& Thien T 1990 Changes in skin blood flow during the menstrual cycle: the influence of the menstrual cycle on the peripheral circulation in healthy female volunteers. Clinical Sciences 78 527-532.

Bartelink ML, De Wit A, Wollersheim H, Theeuwes A \& Thien T 1993 Skin vascular reactivity in healthy subjects: influence of hormonal status. Journal of Applied Physiology 74 727-732. 
Benyon RC 1989 The human skin mast cell. Clinical and Experimental Allergy 19 375-387.

Boesiger J, Tsai M, Maurer M, Yamaguchi M, Brown LF, Claffey KP, Dvorak HF \& Galli SJ 1998 Mast cells can secrete vascular permeability factor/vascular endothelial cell growth factor and exhibit enhanced release after immunoglobulin E-dependent upregulation of $\mathrm{Fc}$ epsilon receptor I expression. Journal of Experimental Medicine 188 1135-1145.

Bungum L, Kvernebo K, Oian P \& Maltau JM 1996 Laser Doppler-recorded reactive hyperaemia in the forearm skin during the menstrual cycle. British Journal of Obstetrics and Gynaecology 103 70-75.

Chambliss KL \& Shaul PW 2002 Estrogen modulation of endothelial nitric oxide synthase. Endocrine Reviews 23 665-686.

Chan NN, MacAllister RJ, Colhoun HM, Vallance P \& Hingorani AD 2001 Changes in endothelium-dependent vasodilatation and alpha-adrenergic responses in resistance vessels during the menstrual cycle in healthy women. Journal of Clinical Endocrinology and Metabolism 86 2499-2504.

Charkoudian N \& Johnson JM 1999a Reflex control of cutaneous vasoconstrictor system is reset by exogenous female reproductive hormones. Journal of Applied Physiology 87 381-385.

Charkoudian N \& Johnson JM 1999b Altered reflex control of cutaneous circulation by female sex steroids is independent of prostaglandins. American Journal of Physiology - Heart and Circulatory Physiology 276 H1634-H1640.

Charlesworth EN 1997 The role of basophils and mast cells in acute and late reactions in the skin. Allergy 52 31-43.

Chen Z, Yuhanna IS, Galcheva-Gargova Z, Karas RH, Mendelsohn ME \& Shaul PW 1999 Estrogen receptor alpha mediates the nongenomic activation of endothelial nitric oxide synthase by estrogen. Journal of Clinical Investigation 103 401-406.

Clifton VL, Read MA, Leitch IM, Giles WB, Boura AL, Robinson PJ \& Smith R 1995 Corticotropin-releasing hormone-induced vasodilatation in the human fetal-placental circulation: involvement of the nitric oxide-cyclic guanosine $3^{\prime}, 5^{\prime}$-monophosphate-mediated pathway. Journal of Clinical Endocrinology and Metabolism $\mathbf{8 0}$ 2888-2893.

Clifton VL, Crompton R, Smith R \& Wright IM 2002 Microvascular effects of CRH in human skin vary in relation to gender. Journal of Clinical Endocrinology and Metabolism 87 267-270.

Cocchiara R, Albeggiani G, Di Trapani G, Azzolina A, Lampiasi N, Rizzo F \& Geraci D 1990 Modulation of rat peritoneal mast cell and human basophil histamine release by estrogens. International Archives of Allergy and Immunology 93 192-197.

Crompton R, Clifton VL, Bisits AT, Read MA, Smith R \& Wright IM 2003 Corticotropin-releasing hormone causes vasodilation in human skin via mast cell-dependent pathways. Journal of Clinical Endocrinology and Metabolism 88 5427-5432.

Eady RA, Cowen T, Marshall TF, Plummer V \& Greaves MW 1979 Mast cell population density, blood vessel density and histamine content in normal human skin. British Journal of Dermatology $\mathbf{1 0 0}$ 623-633.

Feldman MJ, Morris GP, Dinda PK \& Paterson WG 1996 Mast cells mediate acid-induced augmentation of opossum esophageal blood flow via histamine and nitric oxide. Gastroenterology 110 121-128.

Forte P, Kneale BJ, Milne E, Chowienczyk PJ, Johnston A, Benjamin N \& Ritter JM 1998 Evidence for a difference in nitric oxide biosynthesis between healthy women and men. Hypertension 32 $730-734$.

Freedman RR \& Girgis R 2000 Effects of menstrual cycle and race on peripheral vascular alpha-adrenergic responsiveness. Hypertension $35795-799$.

Gaston B, Drazen JM, Loscalzo J \& Stamler JS 1994 The biology of nitrogen oxides in the airways. American Journal of Respiratory and Critical Care Medicine 149 538-551.
Gerhardt U, Hillebrand U, Mehrens T \& Hohage H 2000 Impact of estradiol blood concentrations on skin capillary laser Doppler flow in premenopausal women. International Journal of Cardiology 75 59-64.

Giannattasio C, Failla M, Grappiolo A, Stella ML, Del Bo A, Colombo M \& Mancia G 1999 Fluctuations of radial artery distensibility throughout the menstrual cycle. Arteriosclerosis, Thrombosis, and Vascular Biology 19 1925-1929.

Gilligan DM, Quyyumi AA \& Cannon RO 3rd 1994 Effects of physiological levels of estrogen on coronary vasomotor function in postmenopausal women. Circulation 89 2545-2551.

Grossmann M, Jamieson MJ \& Kirch W 1999 Histamine response and local cooling in the human skin: involvement of $\mathrm{H} 1-$ and H2-receptors. British Journal of Clinical Pharmacology 48 216-222.

Haeggstrom A, Ostberg B, Stjerna P, Graf P \& Hallen H 2000 Nasal mucosal swelling and reactivity during a menstrual cycle. ORL; Journal for Oto-Rhino-Laryngology and its Related Specialties 62 $39-42$.

Hashimoto M, Akishita M, Eto M, Ishikawa M, Kozaki K, Toba K, Sagara Y, Taketani Y, Orimo H \& Ouchi Y 1995 Modulation of endothelium-dependent flow-mediated dilatation of the brachial artery by sex and menstrual cycle. Circulation 92 3431-3435.

Hu J, Norman M, Wallensteen M \& Gennser G 1998 Increased large arterial stiffness and impaired acetylcholine induced skin vasodilatation in women with previous gestational diabetes mellitus. British Journal of Obstetrics and Gynaecology 105 1279-1287.

Jain V, Vedernikov YP, Saade GR, Chwalisz K \& Garfield RE 1997 The relaxation responses to corticotropin-releasing factor in rat aorta are endothelium dependent and gestationally regulated. American Journal of Obstetrics and Gynecology 176 234-240.

Jonassen F, Granerus G \& Wetterqvist H 1976 Histamine metabolism during the menstrual cycle. Acta Obstetrica et Gynecologica Scandinavica 55 297-304.

Kalogeromitros D, Katsarou A, Armenaka M, Rigopoulos D, Zapanti M \& Stratigos I 1995 Influence of the menstrual cycle on skin-prick test reactions to histamine, morphine and allergen. Clinical and Experimental Allergy 25 461-466.

Kawano H, Motoyama T, Kugiyama K, Hirashima O, Ohgushi M, Yoshimura M, Ogawa H, Okumura K \& Yasue H 1996 Menstrual cyclic variation of endothelium-dependent vasodilation of the brachial artery: possible role of estrogen and nitric oxide. Proceedings of the Association of American Physicians 108 473-480.

Kellogg DL Jr, Crandall CG, Liu Y, Charkoudian N \& Johnson JM 1998 Nitric oxide and cutaneous active vasodilation during heat stress in humans. Journal of Applied Physiology 85 824-829.

Kim MS, Chae HJ, Shin TY, Kim HM \& Kim HR 2001 Estrogen regulates cytokine release in human mast cells. Immunopharmacology and Immunotoxicology 23 495-504.

Kono M, Nagata H, Umemura S, Kawana S \& Osamura RY 2001 In situ expression of corticotropin-releasing hormone $(\mathrm{CRH})$ and proopiomelanocortin (POMC) genes in human skin. FASEB Journal 15 2297-2299.

Kubli S, Waeber B, Dalle-Ave A \& Feihl F 2000 Reproducibility of laser Doppler imaging of skin blood flow as a tool to assess endothelial function. Journal of Cardiovascular Pharmacology 36 640-648.

Leitch IM, Boura AL, Botti C, Read MA, Walters WA \& Smith R 1998 Vasodilator actions of urocortin and related peptides in the human perfused placenta in vitro. Journal of Clinical Endocrinology and Metabolism 83 4510-4513.

Lowman MA, Benyon RC \& Church MK 1988 Characterization of neuropeptide-induced histamine release from human dispersed skin mast cells. British Journal of Pharmacology 95 121-130.

Majmudar NG, Robson SC \& Ford GA 2000 Effects of the menopause, gender, and estrogen replacement therapy on vascular nitric oxide activity. Journal of Clinical Endocrinology and Metabolism 85 1577-1583. 
Maurer M, Theoharides T, Granstein RD, Bischoff SC, Bienenstock J, Henz B, Kovanen P, Piliponsky AM, Kambe N, Vliagoftis H et al. 2003 What is the physiological function of mast cells? Experimental Dermatology 12 886-910.

New G, Duffy SJ, Harper RW \& Meredith IT 2000 Long-term oestrogen therapy is associated with improved endotheliumdependent vasodilation in the forearm resistance circulation of biological males. Clinical and Experimental Pharmacology and Physiology 27 25-33.

Nicovani S \& Rudolph MI 2002 Estrogen receptors in mast cells from arterial walls. Biocell 26 15-24.

Pang X, Cotreau-Bibbo MM, Sant GR \& Theoharides TC 1995 Bladder mast cell expression of high affinity oestrogen receptors in patients with interstitial cystitis. British Journal of Urology 75 154-161.

Pang X, Alexacos N, Letourneau R, Seretakis D, Gao W, Boucher W, Cochrane DE \& Theoharides TC 1998 A neurotensin receptor antagonist inhibits acute immobilization stress-induced cardiac mast cell degranulation, a corticotropin-releasing hormone-dependent process. Journal of Pharmacology and Experimental Therapeutics 287 307-314.

Pinto S, Virdis A, Ghiadoni L, Bernini G, Lombardo M, Petraglia F, Genazzani AR, Taddei S \& Salvetti A 1997 Endogenous estrogen and acetylcholine-induced vasodilation in normotensive women. Hypertension 29 268-273.

Sader MA \& Celermajer DS 2002 Endothelial function, vascular reactivity and gender differences in the cardiovascular system. Cardiovascular Research 53 597-604.

Schmolke B, Amon U, Zemcke N \& Wolff HH 1994 Immunohistochemical studies with skin mast cells. Agents and Actions 41 Spec No C49-C50.

Shastry S, Minson CT, Wilson SA, Dietz NM \& Joyner MJ 2000 Effects of atropine and L-NAME on cutaneous blood flow during body heating in humans. Journal of Applied Physiology 88 467-472.

Singh LK, Pang X, Alexacos N, Letourneau R \& Theoharides TC 1999 Acute immobilization stress triggers skin mast cell degranulation via corticotropin releasing hormone, neurotensin, and substance P: A link to neurogenic skin disorders. Brain, Behavior, and Immunity 13 225-239.

Slominski A, Wortsman J, Pisarchik A, Zbytek B, Linton EA, Mazurkiewicz JE \& Wei ET 2001 Cutaneous expression of corticotropin-releasing hormone $(\mathrm{CRH})$, urocortin, and $\mathrm{CRH}$ receptors. FASEB Journal 15 1678-1693.

Slominski A, Pisarchik A, Tobin DJ, Mazurkiewicz JE \& Wortsman J 2004 Differential expression of a cutaneous corticotropin-releasing hormone system. Endocrinology 145 941-950.

Sudhir K, Jennings GL, Funder JW \& Komesaroff PA 1996 Estrogen enhances basal nitric oxide release in the forearm vasculature in perimenopausal women. Hypertension 28 330-334.

Theoharides TC, Singh LK, Boucher W, Pang X, Letourneau R, Webster E \& Chrousos G 1998 Corticotropin-releasing hormone induces skin mast cell degranulation and increased vascular permeability, a possible explanation for its proinflammatory effects. Endocrinology 139 403-413.

Thornton MJ, Taylor AH, Mulligan K, Al-Azzawi F, Lyon CC, O'Driscoll J \& Messenger AG 2003 The distribution of estrogen receptor beta is distinct to that of estrogen receptor alpha and the androgen receptor in human skin and the pilosebaceous unit. Journal of Investigative Dermatology. Symposium Proceedings 8 100-103.

Vliagoftis H, Dimitriadou V, Boucher W, Rozniecki JJ, Correia I, Raam S \& Theoharides TC 1992 Estradiol augments while tamoxifen inhibits rat mast cell secretion. International Archives of Allergy and Immunology 98 398-409.

Wiesner-Menzel L, Schulz B, Vakilzadeh F \& Czarnetzki BM 1981 Electron microscopical evidence for a direct contact between nerve fibres and mast cells. Acta Dermatovenereologica 61 465-469.

Williams MR, Westerman RA, Kingwell BA, Paige J, Blombery PA, Sudhir K \& Komesaroff PA 2001 Variations in endothelial function and arterial compliance during the menstrual cycle. Journal of Clinical Endocrinology and Metabolism 86 5389-5395.

Wyckoff MH, Chambliss KL, Mineo C, Yuhanna IS, Mendelsohn ME, Mumby SM \& Shaul PW 2001 Plasma membrane estrogen receptors are coupled to endothelial nitric-oxide synthase through Galpha(i). Journal of Biological Chemistry 276 27071-27076.

Zhao XJ, McKerr G, Dong Z, Higgins CA, Carson J, Yang ZQ \& Hannigan BM 2001 Expression of oestrogen and progesterone receptors by mast cells alone, but not lymphocytes, macrophages or other immune cells in human upper airways. Thorax 56 205-211.

Received 22 March 2005

Accepted 15 April 2005 